\title{
Productivity and Economic Growth in Switzerland 1991-2006
}

\author{
Barbara Rudolf and Mathias Zurlinden ${ }^{a}$
}

JEL-Classification: E31, E37

Keywords: growth accounting, multi-factor productivity, capital services, constant-quality labour

\section{Introduction}

The purpose of this paper is to examine the sources of economic growth over the period 1991-2006. The technique is growth accounting. Growth accounting is based on the idea that output growth is related to growth in the services derived from the factors of production - capital and labour. The residual provides an estimate of growth in multi-factor productivity (MFP). Basically, it measures the shift in the production function. Early examples of growth accounting can be found in Tinbergen (1942) and Solow (1957). Jorgenson and Griliches (1967) developed the approach further, stressing that it is important to account for substitution between different types of capital and labour. Other important contributions by Jorgenson and various co-authors are collected in JoRGENSON (1995). Useful summaries are provided by Hulten (2000) and the OECD (2001).

Since multi-factor productivity is computed as a residual, the measurement of the input factors is an important issue. Jorgenson and GriLiches (1967) pointed out that the relevant capital input is not the capital stock but the capital services generated by this stock during a given period. Differences between the two concepts matter if the capital stock is heterogenous and the composition of the capital stock changes over time. Similarly, the relevant labour input is not simply the number of workers employed in the economy. Some workers are more productive than others and therefore measures of labour input should account for changes in the composition of the workforce.

a Swiss National Bank, CH-8022 Zurich.Email: barbara.rudolf@snb.ch, mathias.zurlinden@ snb.ch. We thank Thomas Bolli, Ulrich Kohli and an anonymous referee for valuable comments and suggestions. The paper represents the views of the authors and does not necessarily reflect those of the Swiss National Bank. 
By taking into account the effects of changes in the composition of labour and capital, the decomposition of output rise from three contributions to output growth (capital input, labour input, multi-factor productivity) to five contributions (capital stocks, capital quality, labour hours, labour quality, multi-factor productivity). Because growth in multi-factor productivity is calculated as a residual, it can be expected to be smaller in size than in traditional calculations if labour quality and capital quality are increasing over time.

The index of capital services used in this paper is described in detail in Rudolf and ZurLinden (2009). It is calculated as an average of twelve asset stocks, each weighted by its rental price. A similar disaggregation can be applied to the index of labour input based on data for the volume and the average wages of hours worked, broken down by education, age and gender. The data for quality-adjusted labour input are taken from Bolli and ZurLinden (2009).

The paper is organised as follows. Section 2 outlines the methodology. Section 3 presents the results. Section 4 extends the results in two directions. First, the open economy decomposition proposed by Diewert and Morrison (1986) and KoHLI (2004) is applied to the data. This decomposition allows us to calculate the contribution from changes in the terms of trade which is similar in terms of effects on welfare to changes in productivity. Second, the results are compared to those provided by the Swiss Federal Statistical Office (SFSO). Section 5 concludes. The description of the data and detailed annual results are given in two appendices.

\section{Methodology}

The basic idea of growth accounting is to break down the growth in output into the contributions from the growth in labour input and the growth in capital input. Assuming that the factors are paid their social marginal products, the residual can be interpreted as a measure of growth in multi-factor productivity. The methodology is described in the work of Dale Jorgenson and co-authors (see e.g. Jorgenson and Stiroh, 2000). The OECD (2001) manual provides practical guidelines along the same lines.

Let the production function be

$$
Y_{t}=f\left(K_{t}, L_{t}, t\right),
$$

where $Y_{t}$ is the quantity of output, $K_{t}$ and $L_{t}$ measure capital input and labour input. The production function is allowed to shift over time to account for 
technological change. We assume that the production function is linearly homogeneous, increasing, and concave with respect to the two input quantities. In what follows, we will also assume competitive behaviour and profit maximisation. We describe the measurement of capital input and labour input, and we derive the index of multi-factor productivity.

\subsection{Capital Input}

We construct measures of the capital stock of each asset by the perpetual inventory method. Assuming that investments are spread evenly over the period, the end-of-period capital stock can be written as

$$
B_{i, t}=\sum_{\beta=0}^{\infty} I_{i, t-\beta}\left(1-\delta_{i}\right)^{\beta}\left(1-\frac{\delta_{i}}{2}\right)
$$

or, alternatively, as

$$
B_{i, t}=\left(1-\frac{\delta_{i}}{2}\right) A_{i, t}
$$

and

$$
A_{i, t}=I_{i, t}+\left(1-\delta_{i}\right) A_{i, t-1}
$$

for $i=1,2, \ldots, m$, where $B_{i, t}$ denotes the capital stock of the $i$-th asset at the end of period $t, A_{i, t}$ is the corresponding capital stock if investment is assumed to be carried out at the end of the period (instead of spread evenly over the period), $I_{i, t}$ is the investment in asset type $i$ during period $t$, and $\delta_{i}$ is the geometric rate of depreciation of the $i$-th asset which is assumed to be constant over time (see e.g. Oulton and Srinivasan, 2003).

The capital input is not the capital stock itself but the capital services derived from this stock during a certain period. In what follows, we assume that the capital services move in proportion to the capital stock in the middle of the period, $\bar{B}$. Setting the proportionality factor to be equal to 1 , we have

$$
K_{i, t}=\bar{B}_{i, t}=\left(B_{i, t} B_{i, t-1}\right)^{1 / 2} .
$$

The rental price of the capital input, $U_{i, t}$, can then be shown to be

$$
U_{i, t}=r_{t} P_{i, t-1}+\delta_{i} P_{i, t}-\left(P_{i, t}-P_{i, t-1}\right),
$$


where $P_{i, t}$ describes the observable market price of new investment goods of type $i$, and $r_{t}$ is the nominal rate of return on capital derived from

$$
\Pi_{t}=\sum_{i=1}^{m} U_{i, t} K_{i, t}=\sum_{i=1}^{m}\left(r_{t} P_{i, t-1}+\delta_{i} P_{i, t}-\left(P_{i, t}-P_{i, t-1}\right)\right) K_{i, t},
$$

where total profits $\Pi_{t}$ are measured by data on property compensation.

With these ingredients, we can compute the rate of change of capital services as a Törnqvist index

$$
\triangle \ln K_{t}=\sum_{i=1}^{m} \bar{s}_{i, t}^{k} \Delta \ln K_{i, t},
$$

where

$$
\bar{s}_{i, t}^{k}=\frac{s_{i, t}^{k}+s_{i, t-1}^{k}}{2} \text { and } s_{i, t}^{k}=\frac{U_{i, t} K_{i, t}}{\sum_{i=1}^{m} U_{i, t} K_{i, t}} .
$$

Thus, the rate of change of capital services corresponds to the aggregated rates of changes of the net capital stocks of the individual asset stocks, where the weights are the shares in total profits of those asset stocks. The shares in total profits are computed based on the service prices and the asset stocks of the various assets.

Capital input is measured by capital services. An alternative measure of capital is the net (wealth) capital stock. The rate of change of the net (wealth) capital stock corresponds to the aggregated rates of changes of the net capital stocks of the individual asset stocks, where the weights are the shares in total wealth of these assets stocks. The shares in total wealth are computed based on the asset prices of new investment and the asset stocks of the various assets. This yields

$$
\triangle \ln \bar{B}_{t}=\sum_{i=1}^{m} \bar{s}_{i, t}^{b} \Delta \ln \bar{B}_{i, t},
$$

where

$$
\bar{s}_{i, t}^{b}=\frac{s_{i, t}^{b}+s_{i, t-1}^{b}}{2} \text { and } s_{i, t}^{b}=\frac{P_{i, t} B_{i, t}}{\sum_{i=1}^{m} P_{i, t} B_{i, t}} .
$$


Notice that the changes in capital services and changes in the capital stock are identical when the capital stock is homogeneous. When the capital stock is not homogeneous, however, the growth rates will differ, reflecting differences in the rental price to asset price ratios. Following Jorgenson and STIROH (2000), we will use this relationship to decompose the changes in the capital input (capital services) into the contribution from changes in the net (wealth) capital stock and the contribution from changes in the composition of the capital stock. The ratio of aggregate capital services to aggregate capital stock is called the index of capital quality.

The growth rates of capital quality are calculated as

$$
\Delta \ln Q_{t}^{K}=\Delta \ln K_{t}-\triangle \ln \bar{B}_{t}=\sum_{i=1}^{m}\left(\bar{s}_{i, t}^{k}-\bar{s}_{i, t}^{b}\right) \Delta \ln \bar{B}_{i, t} .
$$

From Equation (10), the index of capital quality is easily computed by adding up the growth rates, taking anti-logs, and indexing the resulting series to a base year.

\subsection{Labour Input}

Labour services are easier to handle than capital services. Whereas the rental prices of capital generally cannot be observed and have to be computed as described above, the rental prices of labour services can be measured by wages. Let $\ln \left(L_{t} / \mathrm{L}_{t-1}\right)$ be the rate of change of labour input, where $L_{t}$ is the aggregate quality-adjusted labour input. We then have

$$
\triangle \ln L_{t}=\sum_{j=1}^{J} \bar{s}_{j, t}^{l} \Delta \ln h_{j, t}
$$

where

$$
\bar{s}_{j, t}^{l}=\frac{s_{j, t}^{l}+s_{j, t-1}^{l}}{2} .
$$

The share of labour compensation of group $j, s_{j, t}^{l}$, is defined as 


$$
s_{j, t}^{l}=\frac{\sum_{\substack{i=1 \\ i \varepsilon j}}^{I} \omega_{i, t} h_{i, t} q_{i, t}}{\sum_{j=1}^{J} \sum_{\substack{i=1 \\ i \varepsilon j}}^{I} \omega_{i, j, t} h_{i, j, t} q_{i, j, t}},
$$

and the total hours worked by group $j, h_{j, t}$, are defined as

$$
h_{j, t}=\sum_{\substack{i=1 \\ i \varepsilon j}}^{I} \omega_{i, t} h_{i, t},
$$

where $h_{i, t}$ and $q_{i, t}$ denote the number of hours worked by individual $i$ and the wage rate of individual $i, \omega_{i, t}$ is a correction factor that accounts for differences between sample and population, and $I$ is the number of workers in group $j$ (see Bolli and ZuRLINDEN, 2009). ${ }^{1}$ In this paper, worker groups are defined by education, gender and age, where age is used as a proxy for experience (on-the-job training). As described in the appendix, we define five age groups and five education groups. This gives a total of 50 worker groups.

The changes in the quality-adjusted labour input can be decomposed into changes in unadjusted (raw) hours worked and changes in labour quality. To calculate growth of labour quality, we first calculate the total number of hours worked in the economy, $H_{t}$, as

$$
H_{t}=\frac{L_{t}}{Q_{t}^{L}}=\sum_{j=1}^{J} \sum_{\substack{i=1 \\ i \varepsilon j}}^{I} \omega_{i, j, t} h_{i, j, t} .
$$

The growth rates for labour quality, $\Delta \ln Q_{t}{ }^{L}$, are then obtained by

$$
\triangle \ln Q_{t}^{L}=\Delta \ln L_{t}-\triangle \ln H_{t}
$$

From Equation (15), the index of labour quality is computed easily by adding up the growth rates, taking anti-logs, and indexing the resulting series to a base year.

1 The correction factor $\omega_{i, t}$ is provided by the SFSO (see Appendix A on data). It corrects for the fact that the probability of being sampled is not the same for all individuals. 


\subsection{Multi-Factor Productivity}

The rate of change of total inputs is a weighted average of the rate of change of labour and capital input, with the respective cost shares as weights:

$$
\Delta \ln X_{t}=\bar{s}_{t}^{L} \Delta \ln L_{t}+\bar{s}_{t}^{K} \Delta \ln K_{t},
$$

where

$$
\bar{s}_{t}^{L}=\frac{s_{t}^{L}+s_{t-1}^{L}}{2}, \bar{s}_{t}^{K}=\frac{s_{t}^{K}+s_{t-1}^{K}}{2}, s_{t}^{L}=\frac{w_{t} L_{t}}{C_{t}}, s_{t}^{K}=\frac{\sum_{i=1}^{m} U_{i, t} K_{i, t}}{C_{t}} .
$$

With $w_{t} L_{t}$ denoting the remuneration for labour input in period $t$ and

$$
\sum_{i=1}^{m} U_{i, t} K_{i, t}
$$

denoting the remuneration for capital input, total costs of inputs are

$$
C_{t}=w_{t} L_{t}+\sum_{i=1}^{m} U_{i, t} K_{i, t}
$$

Finally, growth in multi-factor productivity, $\Delta \ln R_{t}$, is the difference between output growth and input growth, that is

$$
\Delta \ln R_{t}=\Delta \ln Y_{t}-\Delta \ln X_{t} .
$$

\subsection{Decomposition of Growth in Output and Average Labour Productivity (ALP)}

In a growth accounting exercise, the growth in output, $\ln \left(Y_{t} / Y_{t-1}\right)$, is basically broken down into the contributions of growth in capital input, labour input and multi-factor productivity. This can be written as

$$
\Delta \ln Y_{t}=\bar{s}_{t}^{K} \Delta \ln K_{t}+\bar{s}_{t}^{L} \Delta \ln L_{t}+\Delta \ln R_{t}
$$


or, in the extended version, with capital input decomposed into contributions from the capital stock and capital quality, and labour input decomposed into the contributions from total hours worked and labour quality, as

$$
\Delta \ln Y_{t}=\bar{s}_{t}^{K}\left(\Delta \ln \bar{B}_{t}+\Delta \ln Q_{t}^{K}\right)+\bar{s}_{t}^{L} \cdot\left(\Delta \ln H_{t}+\Delta \ln Q_{t}^{L}\right)+\Delta \ln R_{t} .
$$

Alternatively, it is often convenient to present results as decomposition of growth in labour productivity. Given the assumption of constant returns to scale, we can write

$$
\Delta \ln \frac{Y_{t}}{H_{t}}=\bar{s}_{t}^{K} \Delta \ln \frac{K_{t}}{H_{t}}+\bar{s}_{t}^{L} \Delta \ln Q_{t}^{L}+\Delta \ln R_{t} .
$$

That is, the growth rates of average labour productivity are decomposed into the contributions from three sources: the substitution between capital and labour, also called capital deepening, $K_{t} / H_{t}$, labour quality, $\mathrm{Q}_{t}{ }^{L}$, and multi-factor productivity, $R_{t}{ }^{2}$

\section{Results}

Based on the methodology described in Section 2, we can decompose growth in output into the contributions from the various input factors. The residual is a measure of growth in multi-factor productivity. All data are annual. The period is 1991 to 2006 (1992-2006 for growth rates), and is determined by data availability. ${ }^{3}$ A description of the data can be found in Appendix A.

The results for annual growth in multi-factor productivity are displayed in Figure 1. They suggest that multi-factor productivity is rather volatile. This is hardly surprising if we look at the list of factors which may influence the residual that is used as an estimate of growth in multi-factor productivity. According to Hulten (2000), the following factors may play a role: technical innovation, organisational and institutional change, shifts in societal attitudes, fluctuations in demand, omitted variables, and measurement errors.

2 We follow the convention that labour productivity is defined as $Y_{t} / H_{t}$, not $Y_{t} / L_{t}$.

3 The investment data for the 12 asset classes start in 1990. The series for total hours worked used in this paper starts in 1991. 
Figure 1: Growth in MFP vs. growth in ALP

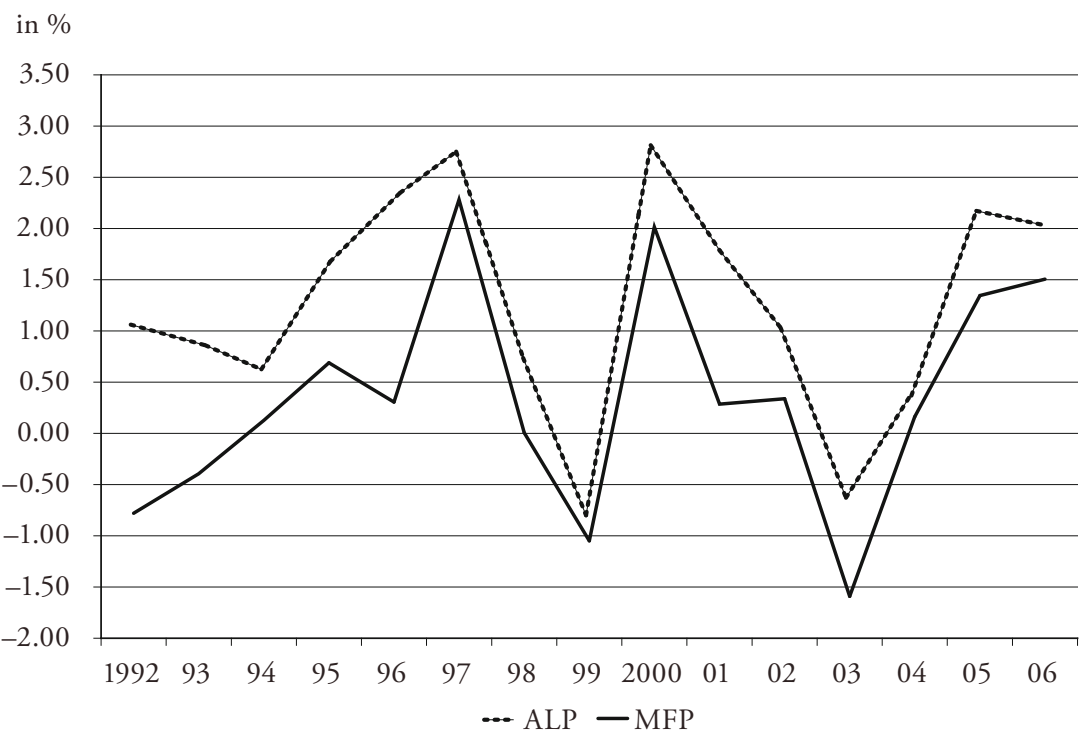

We cannot control most of these elements. ${ }^{4}$ However, to reduce the influence of fluctuations in demand, it is straightforward to evaluate the results in terms of averages over multi-year periods. This is what we are going to do in this section and what is actually done in most studies of growth accounting. The multiyear periods are the full period (1991-2006) and two subperiods (1991-2000, 2000-2006).

Table 1 summarises the decomposition of output growth. Detailed annual results are presented in Appendix B. For the full period, we find that capital input and labour input contribute $0.57 \mathrm{pp}$ and $0.52 \mathrm{pp}$, respectively, to the average annual GDP growth rate of 1.44 percent. The remaining 0.35 pp measure

4 Starting with Solow (1957), various authors have adjusted input factors to account for variable factor utilisation. Early attempts tended to be overly simplistic. More recently, Susanto Basu and John Fernald proposed an approach based on industry data and using the idea that changes in hours per worker can proxy for unobserved changes in factor utilisation (see e.g. Basu, Fernald and Kimball, 2006). For Switzerland, however, we do not have data on capital input by industry because data on investment by industry are not available. 
growth in multi-factor productivity. Thus, the proportion attributable to multifactor productivity amounts to 24 percent of GDP growth for Switzerland, while 76 percent are attributed to the input factors. Decomposing growth in capital input, we find that both the capital stock and the index of capital quality have grown over time, but the contribution of growth in capital quality is considerably smaller than that of growth in the capital stock. 17 percent of capital input growth can be attributed to changes in capital quality and 83 percent to growth in the capital stock. To some extent, the contribution of changes in capital quality reflects the large increase in IT investments. As IT assets are characterised by high rental to asset price ratios, they cause the index of capital services to increase more rapidly than the capital stock index. ${ }^{5}$ The decomposition of labour input reveals that the contribution of growth in labour quality predominates over the contribution from growth in labour hours. 75 percent of labour input growth are attributable to changes in labour quality and just 25 percent to changes in labour hours. This suggests that labour quality growth is essential to the growth in labour input and that measures of growth in multi-factor productivity significantly depend on whether or not labour quality is explicitly taken into account.

Table 1: Decomposition of Output Growth 1991-2006

\begin{tabular}{lccc}
\hline & 1991-2006 & 1991-2000 & 2000-2006 \\
\hline Real output (GDP) & 1.44 & 1.28 & 1.68 \\
Contribution from labour input & 0.52 & 0.29 & 0.86 \\
$\quad$ Labour hours & 0.13 & -0.03 & 0.38 \\
$\quad$ Labour quality & 0.39 & 0.33 & 0.48 \\
Contribution from capital input & 0.57 & 0.63 & 0.47 \\
$\quad$ Capital stock & 0.47 & 0.55 & 0.36 \\
Capital quality & 0.10 & 0.08 & 0.12 \\
Multi-factor productivity (MFP) & 0.35 & 0.36 & 0.34 \\
\hline
\end{tabular}

Notes: Average of annual growth rates in percent (contributions to growth in percentage points). Growth rates are calculated as log differences. Totals may not add due to rounding.

5 In the short run, there may be some cyclical effect on the index of capital quality as shares in profits, $s_{t}^{k}$, do not move one to one with shares in wealth, $s_{t}^{b}$, over the cycle (see e.g. Oulton and Srinivasan, 2003, or Rudolf and Zurlinden, 2009). 
The ordering of the various contributions to output growth is not very robust across sub-periods. In particular, the contribution of growth in labour input was weak during most of the 1990s, but considerably stronger than contributions of capital input and multi-factor productivity in the early 2000s. Among possible reasons are the bilateral agreements with the $\mathrm{EU}$ on the free movement of persons (2002) which brought an inflow of skilled immigrants from Germany and other EU countries. Arvanitis and Bolli (2008) computed indices of labour quality for Swiss workers and immigrant workers from EU-15 countries for the period 1995-2007. They found that labour quality has increased more rapidly for EU-15 immigrant workers than for Swiss workers. However, the labour quality of immigrant workers from the EU-15 does not appear to have grown more rapidly after than before 2002 .

Alternatively, we can display the results as the decomposition of changes in average labour productivity instead of changes in output (Table 2). Since average labour productivity is defined as output per hour worked, growth in output is the sum of growth in labour productivity and growth in hours worked. We decompose growth in labour productivity into the contributions from growth in capital deepening, defined as capital input per hour worked, growth in labour quality, and growth in multi-factor productivity.

Table 2: Decomposition of Growth in Average Labour Productivity 1991-2006

\begin{tabular}{lccc}
\hline & $1991-2006$ & $1991-2000$ & $2000-2006$ \\
\hline Average labour productivity (ALP) & 1.26 & 1.33 & 1.15 \\
Contribution from capital deepening & 0.52 & 0.65 & 0.32 \\
Contribution from labour quality & 0.39 & 0.33 & 0.48 \\
Multi-factor productivity (MFP) & 0.35 & 0.36 & 0.34 \\
\hline
\end{tabular}

Notes: Average of annual growth rates in percent (contributions to growth in percentage points). Growth rates are calculated as log differences. Totals may not add due to rounding.

Growth in labour productivity is substantially larger than growth in multi-factor productivity. The difference reflects positive contributions from growth in capital deepening and growth in labour quality. Furthermore, changes in labour productivity appear to be dominated by changes in multi-factor productivity, reflecting the relatively smooth pattern of capital deepening and labour quality. Growth 
in labour productivity, like growth in multi-factor productivity, is rather volatile over time (see ALP in Figure 1).

It is interesting to look at the changes in labour productivity and multi-factor productivity from the perspective of the IT boom in the late 1990s. Data for the U.S. indicate a substantial increase in productivity growth after 1995 (e.g. JoRGENSON, 2005). This surge is usually attributed to the technical progress in the IT sector and the important role of the IT-producing industries in the U.S. economy. Figure 1 indicates that we do not find such a pattern for Switzerland. Generally, we would expect technological progress in the IT sector to show up in labour productivity growth and multi-factor-productivity growth in the ITproducing industries. In the IT-using industries, however, IT progress should show up in labour productivity growth, but not necessarily in multi-factor-productivity growth. ${ }^{6}$ Accordingly, the question for a country with a relatively small IT-producing sector like Switzerland is why IT has not stimulated labour productivity growth, rather than why it has not stimulated multi-factor-productivity growth.

\section{Alternative Decompositions}

In this section, we present two decompositions that differ in method and/or data from those presented above. The first adjusts output and productivity indexes for changes in the terms of trade. The second uses the data from the multi-factor productivity calculations by the SFSO (2006a).

\subsection{Growth Accounting in the Open Economy}

The decomposition of output growth presented in this section was developed by KoHli (2004), building on the work of Diewert and Morrison (1986). As shown by KoHLI, the growth rate of nominal GDP can be decomposed into the rate of change in domestic prices, $\mathrm{P}_{t}^{D}$, a terms-of-trade effect, $O_{t}$, a trade balance effect, $T_{t}$, and the contributions from capital input, $K_{t}$, labour input, $L_{t}$, and multi-factor productivity, $R_{t}{ }^{7}$

6 See Jorgenson (2005, pp. 778-79).

7 The terms-of-trade effect in KoHLi (2004) differs from the one in Diewert and Morrison (1986) which has the drawback of not being homogenous of degree zero in prices if trade is unbalanced. For an application of the latter to Swiss data, see KoHLI (1993). 
In contrast to the decomposition in Section 2, the starting point is the growth rate of nominal GDP (not real GDP). Furthermore, real GDP is defined as a chained implicit Törnqvist index (whereas it is a chained Laspeyres index in the National Accounts). To account for the openness of the economy, the traditional two-input, one-output production function setting is extended by including imports and exports. We assume a technology with two outputs (domestic goods and exports) and three inputs (labour, capital and imports), where imports are treated as a negative output.

Assuming the translog functional form, the decomposition of output growth into the contributions from labour input, capital input, and multi-factor productivity can be written as

$$
\Delta \ln \tilde{Y}_{t}=\Delta \ln \frac{Y_{t}^{N}}{\tilde{P}_{t}}=\bar{s}_{t}^{K} \Delta \ln K_{t}+\bar{s}_{t}^{L} \Delta \ln L_{t}+\Delta \ln \tilde{R}_{t},
$$

where $\tilde{Y}_{t}$ is the implicit Törnqvist index of real GDP and $\tilde{P}_{t}$ is the Törnqvist GDP deflator. The equation does not differ greatly from the decompositions above, except that the price deflator and real GDP are now defined as a Törnqvist index and an implicit Törnqvist index, respectively. Again, the equation can easily be extended to decompose labour input into total hours worked and the index of labour quality, and capital input into the capital stock and the index of capital quality.

Following KoHLI (2004), the Törnqvist price index can be written as

$$
\Delta \ln \tilde{P}_{t}=\Delta \ln P_{t}^{D}+\bar{s}_{t}^{B} \Delta \ln T_{t}+\bar{s}_{t}^{M} \Delta \ln O_{t},
$$

where

$$
\begin{aligned}
\Delta \ln P_{t}^{D} & =\frac{w_{t}^{C}+w_{t-1}^{C}}{2} \Delta \ln P_{t}^{C}+\frac{w_{t}^{I}+w_{t-1}^{I}}{2} \Delta \ln P_{t}^{I}, \\
O_{t} & =\frac{P_{t}^{X}}{P_{t}^{M}}, \quad T_{t}=\frac{P_{t}^{X}}{P_{t}^{D}}, \\
\bar{s}_{t}^{B} & =\frac{s_{t}^{X}-s_{t}^{M}+s_{t-1}^{X}-s_{t-1}^{M}}{2}, \bar{s}_{t}^{M}=\frac{s_{t}^{M}+s_{t-1}^{M}}{2},
\end{aligned}
$$

with $w_{t}^{C}$ and $w_{t}^{I}$ denoting the shares of consumption (private consumption and government purchases) and investment in nominal domestic expenditures, $s_{t}^{M}$ 
and $s_{t}^{X}$ the shares of imports and exports in nominal GDP, and $P_{t}^{C}, P_{t}^{I}, P_{t}^{M}$ and $P_{t}^{X}$ the corresponding price deflators. The complete decomposition of nominal GDP then is

$$
\begin{aligned}
\Delta \ln Y_{t}^{N}= & \Delta \ln P_{t}^{D}+\bar{s}_{t}^{B} \Delta \ln T_{t}+\bar{s}_{t}^{M} \Delta \ln O_{t} \\
& +\bar{s}_{t}^{L} \Delta \ln L_{t}+\bar{s}_{t}^{K} \Delta \ln K_{t}+\Delta \ln \tilde{R}_{t} .
\end{aligned}
$$

With $\Delta \ln Y_{t}^{D I} \equiv \Delta \ln Y_{t}^{N}-\Delta \ln P_{t}^{D}$, Equation (23) can be rearranged to describe the decomposition of growth in real domestic income.

The results are displayed in Table 3 . The growth rates in real domestic income differ substantially from those in real GDP. ${ }^{8}$ This difference is largely due to the contribution from the terms of trade. The contribution is positive, implying that real GDP tends to underestimate the increase in real domestic income. The contributions from labour input and capital input are unchanged. We therefore do not repeat the results for labour quality and capital quality, and for the capital stock and total hours worked. The trade-balance effect is negligible and growth rates of multi-factor productivity differ little from those reported in Table 1.

Table 3: Open Economy Decomposition of Output Growth 1991-2006

\begin{tabular}{lccc}
\hline & 1991-2006 & 1991-2000 & 2000-2006 \\
\hline Nominal output (GDP) & 2.33 & 2.22 & 2.51 \\
Domestic prices & 0.85 & 0.89 & 0.80 \\
Real domestic income & 1.48 & 1.33 & 1.70 \\
$\quad$ Contribution from labour input & 0.52 & 0.29 & 0.86 \\
Contribution from capital input & 0.57 & 0.63 & 0.47 \\
Contribution from trade balance & -0.02 & -0.02 & -0.02 \\
Contribution from terms of trade & 0.07 & 0.07 & 0.06 \\
Multi-factor productivity (MFP) & 0.35 & 0.36 & 0.34 \\
\hline
\end{tabular}

Notes: Average of annual growth rates in percent (contributions to growth in percentage points). Growth rates are calculated as log differences. Totals may not add due to rounding.

8 It does not matter much whether real GDP is calculated as a chain-linked Laspeyres index (Table 1) or an implicit Törnqvist index for the period under review. The total increase of GDP over the period $1991-2006$ is $24.1 \%$ in both cases. The difference between the Laspeyres and the implicit Törnqvist index with regard to the growth rates for individual years is always below 0.05 percentage point. 
As pointed out by Diewert and Morrison (1986), an improvement in the terms of trade is similar to technological progress, as it raises the net amount of goods that a country obtains for a given effort. Thus, a welfare index can be constructed that captures the effects from changes in multi-factor productivity and in the terms of trade.

\subsection{Growth Accounting by SFSO}

SFSO figures for multi-factor productivity have been available since 2006. ${ }^{9}$ The underlying growth accounting differs from our calculations in various respects. The main difference is that the SFSO's growth accounting does not take changes in labour quality into account. Other differences concern the capital data. In the SFSO calculations, the stocks of each type of asset are end-of-period figures, whereas we use mid-period figures. Also, capital services are assumed to be proportional to the stocks at the end of the period, whereas we set them proportional to the mid-period stocks. Finally, the user costs of capital are defined in real terms and the underlying rate of return is modelled as a constant exogenous rate, whereas we define the user costs of capital in nominal terms and apply the ex-post approach used by Jorgenson and GriLICHES (1967) and others.

Table 4 displays the results of the SFSO's growth accounting taken from the 2009 update. Since the SFSO does not decompose the contribution of growth in capital input, we have constructed a capital stock index based on the stocks for each asset type used by the SFSO to calculate capital services. Thus, the capital stock and the associated index of capital quality are consistent with the SFSO measure of capital input. Comparing the results reported in Table 4 with those in Table 1 shows that the SFSO estimate of growth in multi-factor productivity exceeds our estimate. This largely reflects the contribution from changes in labour quality. In our estimates, changes in labour quality affect changes in labour input, whereas in the SFSO estimates, changes in labour quality are not considered and therefore show up in the growth rate of multi-factor productivity. As labour quality has improved over time, the SFSO estimates of growth in multi-factor productivity are higher on average than our estimates. If we did not account for changes in labour quality in our estimates, differences between the two estimates would largely disappear. This suggests that the effects caused

9 See SFSO (2006a) and www.bfs.admin.ch/bfs/portal/de/index/themen/04/03/blank/key/04. html.

10 For a more detailed account of the differences, see Rudolf and ZurLinden (2009). 
by other methodological and data differences are minor (or largely cancel each other out).

Table 4: Decomposition of Output Growth Based on SFSO Data 1991-2006

\begin{tabular}{lccc}
\hline & $1991-2006$ & $1991-2000$ & $2000-2006$ \\
\hline Real output (GDP) & 1.44 & 1.28 & 1.68 \\
Contribution from total hours worked & 0.13 & -0.03 & 0.38 \\
Contribution from capital input & 0.61 & 0.69 & 0.50 \\
$\quad$ Capital stock & 0.50 & 0.58 & 0.38 \\
$\quad$ Capital quality & 0.11 & 0.11 & 0.12 \\
Multi-factor productivity (MFP) & 0.70 & 0.63 & 0.80 \\
\hline
\end{tabular}

Notes: Average of annual growth rates in percent (contributions to growth in percentage points). Growth rates are calculated as log differences. Totals may not add due to rounding.

\section{Concluding Remarks}

In this paper, we have presented results for calculations of growth in multi-factor productivity in Switzerland over the period 1991-2006. We have decomposed the growth in output and the growth in average labour productivity. Overall, average growth in multi-factor productivity is estimated at 0.35 percent per year.

The estimates of growth in multi-factor productivity are lower than previous estimates. This is largely due to the fact that this paper takes changes in the education-age-gender composition of the workforce explicitly into account. The increase in labour quality is reflected in larger growth rates of labour input and lower growth rates of multi-factor productivity, which is calculated as a residual. Labour quality has increased fairly steadily in the period 1991-2006. In particular, there is no apparent break in trend at or around the date of the introduction of free movement of persons between Switzerland and member states of the EU (2002).

Comparisons with the official estimates of multi-factor productivity by the SFSO suggest that differences are minor, except for the fact that we explicitly consider the effect of labour quality, whereas the SFSO does not. The results are shown to be robust to open economy considerations. Apart from that, robustness issues have not been at the centre of this paper. How the indices of capital input and labour input respond to changes in the underlying sets of assumptions is examined in Rudolf and Zurlinden (2009) and Bolli and Zurlinden (2009). 
Comparisons with results from studies for other countries are hazardous because the studies usually differ with respect to methodology and quality of data. It can be said, however, that we do not find the increase in productivity growth that shows up in calculations with data for the U.S.. In this regard, the results for Switzerland are similar to those for most other European countries.

\section{Appendix}

\section{A. Data}

This appendix provides information on the data underlying the measures of output and prices, capital input, labour input, and the respective cost shares.

\section{A.1 Output and Prices}

The output, denoted $Y_{t}$, is annual gross domestic product (GDP) at constant prices, calculated as a chain-linked Laspeyres index. $P_{t}$ is the corresponding price deflator. All data are taken from the National Accounts.

In Section 4.1, output $\tilde{Y}_{t}$ is calculated as an implicit Törnqvist index, resulting from nominal GDP and the Törnqvist GDP deflator $\tilde{P}_{t}$. The data for the nominal GDP components and the corresponding price deflators are taken from the National Accounts.

\section{A.2 Labour Input}

The labour input, $L_{t}$, is measured as a Törnqvist index of constant-quality hours worked. It corresponds to the product of total hours worked and the index of labour quality. Hours worked are taken from the Work Volume Statistics (SFSO). The Törnqvist index of labour quality is calculated based on the breakdown of workers in five classes relating to education, five classes relating to age, and for the two genders (total: 50 classes). For a detailed description, see Bolli and ZurLinden (2009). The series used in the present study correspond to the Jorgenson-type series presented in that paper.

\section{A.3 Capital}

The capital input, $K_{t}$, is measured as a Törnqvist volume index of capital services. A complete description of the volume indices of capital services and the net capital stock data is given in Rudolf and ZuRLINDEN (2009). 
Capital stocks are calculated with the perpetual inventory method for 12 types of assets (3 for structures and 9 for equipment). Inventories are not considered. Neither are land and tangible assets. The investment data for the 12 assets (volumes and prices) are taken from the National Accounts (annual data 1990-2005). The depreciation rates are calculated as $g / N$, where $g=2$ (double declining rate) and $N$ denotes the service lives. Service lives are taken from SFSO (2006b), except for "growing of crops, market gardening, horticulture, farming of animals" where the authors' own estimate is used (12 years). Starting values of asset stocks in 1989 are calculated based on the assumption that investment of the three types of structures and the nine types of equipment increased at the rate of total structures and total equipment, respectively, from 1947 to 1989, and at the rate of real GDP from 1850 to 1947 (structures) and 1920 to 1947 (equipment). Data for the years before 1948 are taken from Ritzmann-Blickenstorfer (1996). Figures for total profits used to compute the user cost of capital are based on the data for capital compensation from the National Accounts (for the calculation of mixed income, see Section A.4).

\section{A.4 Cost Shares of Labour and Capital}

The cost shares of labour and capital are obtained from data on labour compensation and gross operating surplus in the National Accounts. The data on gross operating surplus include the labour income of self-employed persons (mixed income). Mixed income is calculated based on the assumption that labour compensation does not differ between the self-employed and the rest of the labour force. The figures for labour compensation and gross operating surplus are adjusted accordingly. "Other taxes less subsidies on production and imports" are allocated proportionately to labour and capital.

\section{A.5 Estimates of Multi-Factor Productivity by the SFSO}

A detailed account of the methodology employed by the Swiss Federal Statistical Office is provided by SFSO (2006a). The following summary is focused on the main characteristics and the reasons for differences in results.

Output. As above. Real GDP, chained Laspeyres index.

Capital input. Asset stocks are end-of-period. Capital services in period $t$ are set proportional to the asset stocks at the end of period $t$. Asset stocks are calculated with truncated depreciation; that is, assets of a given vintage are set to zero, once the depreciated value falls below a certain threshold. User cost of capital is defined in real terms and the underlying real rate of return is a 
constant calculated as the average of the real government bond yield and the endogenous real rate of return (both computed as averages over 1990-2005). See Rudolf and Zurlinden (2009) for further details on differences.

Labour input. Labour quality is not considered.

Cost shares of labour and capital. Capital costs are calculated based on the estimated user cost of capital and the asset stocks (see above). Because the rate of return is modelled as a constant, the results differ from the capital compensation (adjusted for mixed income) derived from the National Accounts. Figures for the composition of the labour force used to compute mixed income are taken from the Labour Force Survey (SFSO).

Note that, in 2007, the SFSO published a series for the net capital stock (see www.bfs.admin.ch/bfs/portal/de/index/themen/04/02/04/key/Stock_cap. html). We have not used this series (and have, instead, constructed a series which is consistent with the SFSO series of capital services) for two reasons. First, the SFSO applies a different truncation scheme for the asset stocks used to calculate the net capital stock and aggregate capital services, respectively. Second, in the aggregation, the constant-price asset stocks are simply added together, while we use the Törnqvist formula (see Equation 9). The effects of these differences on the results for the net capital stock are, however, very small.

\section{B. Decompositions: Annual Results}

The key variables are displayed in Table B.1. The table shows output, labour input (total and separately for labour hours and labour quality), capital input (total and separately for capital stock and capital quality), and multi-factor productivity, as indices $1991=100$. Tables B. 2 and B.3 give the detailed results for the decomposition of output growth. 
Table B.1: Output, Input Factors and MFP, Benchmark Case 1991-2006 (see Section 3)

\begin{tabular}{|c|c|c|c|c|c|c|c|c|}
\hline & $\begin{array}{c}Y \\
\text { (1) }\end{array}$ & $\begin{array}{c}L \\
\text { (2) }\end{array}$ & $\begin{array}{l}H \\
\text { (3) }\end{array}$ & $\begin{array}{l}Q^{L} \\
\text { (4) }\end{array}$ & $\begin{array}{c}K \\
\text { (5) }\end{array}$ & $\begin{array}{c}\bar{B} \\
(6)\end{array}$ & $\begin{array}{l}Q^{K} \\
\text { (7) }\end{array}$ & $\begin{array}{c}R \\
(8)\end{array}$ \\
\hline 1991 & 100.00 & 100.00 & 100.00 & 100.00 & 100.00 & 100.00 & 100.00 & 100.00 \\
\hline 1992 & 100.10 & 100.30 & 99.08 & 101.23 & 102.37 & 102.50 & 99.87 & 99.22 \\
\hline 1993 & 99.91 & 99.99 & 98.06 & 101.97 & 103.95 & 104.29 & 99.68 & 98.83 \\
\hline 1994 & 101.10 & 100.86 & 98.61 & 102.28 & 105.53 & 106.13 & 99.43 & 98.96 \\
\hline 1995 & 101.46 & 99.55 & 97.35 & 102.26 & 107.75 & 108.37 & 99.42 & 99.64 \\
\hline 1996 & 102.10 & 99.08 & 95.76 & 103.47 & 110.33 & 110.57 & 99.79 & 99.95 \\
\hline 1997 & 104.22 & 97.91 & 95.09 & 102.97 & 112.89 & 112.57 & 100.28 & 102.25 \\
\hline 1998 & 106.96 & 100.49 & 96.81 & 103.80 & 115.87 & 114.75 & 100.98 & 102.26 \\
\hline 1999 & 108.37 & 102.67 & 98.86 & 103.86 & 119.24 & 117.05 & 101.88 & 101.19 \\
\hline 2000 & 112.25 & 103.73 & 99.55 & 104.20 & 122.58 & 119.34 & 102.71 & 103.25 \\
\hline 2001 & 113.54 & 104.02 & 98.85 & 105.23 & 125.61 & 121.39 & 103.48 & 103.55 \\
\hline 2002 & 114.05 & 103.48 & 98.27 & 105.30 & 128.08 & 122.99 & 104.14 & 103.90 \\
\hline 2003 & 113.82 & 104.91 & 98.71 & 106.28 & 129.94 & 124.32 & 104.52 & 102.26 \\
\hline 2004 & 116.70 & 107.83 & 100.79 & 106.98 & 131.61 & 125.67 & 104.73 & 102.43 \\
\hline 2005 & 119.78 & 109.07 & 101.23 & 107.75 & 133.67 & 127.29 & 105.01 & 103.81 \\
\hline 2006 & 124.13 & 111.43 & 102.78 & 108.42 & 136.18 & 129.18 & 105.42 & 105.39 \\
\hline
\end{tabular}

Notes: Indices $1991=100 . Y=$ output (GDP), $L=$ labour input, $H=$ hours worked, $Q^{L}=$ labour quality (composition of labour), $K=$ capital input, $\bar{B}=$ capital stock, $Q^{K}=$ capital quality (composition of capital), $R=$ multi-factor productivity. 
Table B.2: Decomposition of Output Growth, Benchmark Case 1991-2006 (see Section 3)

\begin{tabular}{|c|c|c|c|c|c|c|c|c|}
\hline & $\begin{array}{c}Y \\
(1)\end{array}$ & $\begin{array}{c}L \\
(2)\end{array}$ & $\begin{array}{l}H \\
(3)\end{array}$ & $\begin{array}{l}Q^{L} \\
(4)\end{array}$ & $\begin{array}{c}K \\
(5)\end{array}$ & $\begin{array}{l}\bar{B} \\
(6)\end{array}$ & $\begin{array}{l}Q^{K} \\
(7)\end{array}$ & $\begin{array}{c}R \\
(8)\end{array}$ \\
\hline 1992 & 0.10 & 0.21 & -0.66 & 0.87 & 0.67 & 0.70 & -0.04 & -0.78 \\
\hline 1993 & -0.19 & -0.22 & -0.74 & 0.52 & 0.43 & 0.49 & -0.05 & -0.39 \\
\hline 1994 & 1.18 & 0.62 & 0.40 & 0.22 & 0.43 & 0.51 & -0.07 & 0.13 \\
\hline 1995 & 0.35 & -0.94 & -0.92 & -0.02 & 0.60 & 0.60 & 0.00 & 0.69 \\
\hline 1996 & 0.63 & -0.34 & -1.19 & 0.85 & 0.66 & 0.56 & 0.10 & 0.31 \\
\hline 1997 & 2.05 & -0.86 & -0.51 & -0.35 & 0.63 & 0.50 & 0.14 & 2.28 \\
\hline 1998 & 2.60 & 1.87 & 1.29 & 0.58 & 0.73 & 0.54 & 0.19 & 0.01 \\
\hline 1999 & 1.30 & 1.56 & 1.51 & 0.04 & 0.80 & 0.55 & 0.25 & -1.05 \\
\hline 2000 & 3.52 & 0.74 & 0.51 & 0.23 & 0.76 & 0.54 & 0.23 & 2.01 \\
\hline 2001 & 1.15 & 0.21 & -0.52 & 0.72 & 0.65 & 0.45 & 0.20 & 0.29 \\
\hline 2002 & 0.44 & -0.39 & -0.44 & 0.05 & 0.49 & 0.33 & 0.16 & 0.34 \\
\hline 2003 & -0.20 & 1.02 & 0.33 & 0.69 & 0.37 & 0.28 & 0.09 & -1.59 \\
\hline 2004 & 2.50 & 1.99 & 1.52 & 0.47 & 0.35 & 0.29 & 0.05 & 0.16 \\
\hline 2005 & 2.61 & 0.82 & 0.31 & 0.51 & 0.44 & 0.36 & 0.08 & 1.34 \\
\hline 2006 & 3.57 & 1.53 & 1.09 & 0.45 & 0.53 & 0.42 & 0.11 & 1.51 \\
\hline \multicolumn{9}{|c|}{ Averages: } \\
\hline $\begin{array}{l}1991- \\
2006\end{array}$ & 1.44 & 0.52 & 0.13 & 0.39 & 0.57 & 0.47 & 0.10 & 0.35 \\
\hline $\begin{array}{l}1991- \\
2000\end{array}$ & 1.28 & 0.29 & -0.03 & 0.33 & 0.63 & 0.55 & 0.08 & 0.36 \\
\hline $\begin{array}{l}2000- \\
2006\end{array}$ & 1.68 & 0.86 & 0.38 & 0.48 & 0.47 & 0.36 & 0.12 & 0.34 \\
\hline
\end{tabular}

Notes: Annual growth rates in percent (contributions to growth in percentage points). Growth rates are calculated as log differences. Totals may not add due to rounding. 
Table B.3: Decomposition of Output Growth, Open Economy Case 1991-2006 (see Section 4.1)

\begin{tabular}{lcrrrrrrr}
\hline & $Y^{N}$ & $P^{D}$ & $O$ & $\tilde{R}$ & $T$ & $L$ & $K$ & $Y^{D I}$ \\
& $(1)$ & $(2)$ & $(3)$ & $(4)$ & $(5)$ & $(6)$ & $(7)$ & $(8)$ \\
\hline 1992 & 2.10 & 2.37 & -0.37 & -0.73 & -0.05 & 0.21 & 0.67 & -0.27 \\
1993 & 2.17 & 1.24 & 1.07 & -0.39 & 0.04 & -0.22 & 0.43 & 0.93 \\
1994 & 2.44 & -0.01 & 1.26 & 0.16 & -0.02 & 0.62 & 0.43 & 2.46 \\
1995 & 1.08 & 0.02 & 0.73 & 0.69 & -0.01 & -0.94 & 0.60 & 1.07 \\
1996 & 0.82 & 0.51 & -0.24 & 0.31 & -0.08 & -0.34 & 0.66 & 0.31 \\
1997 & 1.92 & 0.89 & -0.98 & 2.25 & -0.01 & -0.86 & 0.63 & 1.03 \\
1998 & 2.89 & -0.20 & 0.49 & 0.01 & 0.00 & 1.87 & 0.73 & 3.09 \\
1999 & 1.92 & 1.01 & -0.27 & -1.08 & -0.09 & 1.56 & 0.80 & 0.91 \\
2000 & 4.64 & 2.17 & -1.05 & 1.98 & 0.04 & 0.74 & 0.76 & 2.48 \\
2001 & 1.94 & 0.92 & -0.10 & 0.29 & -0.04 & 0.21 & 0.65 & 1.02 \\
2002 & 0.91 & -0.86 & 1.43 & 0.33 & -0.09 & -0.39 & 0.49 & 1.77 \\
2003 & 0.80 & 0.23 & 0.73 & -1.58 & 0.02 & 1.02 & 0.37 & 0.56 \\
2004 & 3.07 & 0.85 & -0.25 & 0.16 & -0.02 & 1.99 & 0.35 & 2.22 \\
2005 & 2.71 & 1.13 & -0.98 & 1.33 & -0.02 & 0.82 & 0.44 & 1.59 \\
2006 & 5.61 & 2.54 & -0.50 & 1.50 & 0.01 & 1.53 & 0.53 & 3.07 \\
\hline Averages: & & & & & & & & \\
$1991-$ & 2.33 & 0.85 & 0.07 & 0.35 & -0.02 & 0.52 & 0.57 & 1.48 \\
2006 & & & & & & & & \\
$1991-$ & 2.22 & 0.89 & 0.07 & 0.36 & -0.02 & 0.29 & 0.63 & 1.33 \\
2000 & & & & & & & & \\
$2000-$ & 2.51 & 0.80 & 0.06 & 0.34 & -0.02 & 0.86 & 0.47 & 1.70 \\
2006 & & & & & & & & \\
\hline
\end{tabular}

Notes: Annual growth rates in percent (contributions to growth in percentage points). Growth rates are calculated as $\log$ differences. Totals may not add due to rounding. $Y^{N}=$ nominal GDP, $P^{D}=$ price index of domestic expenditures, $O=$ terms of trade, $\tilde{R}=$ multi-factor productivity, $T=$ trade balance, $L=$ labour input, $K=$ capital input, $Y^{D I}=$ real domestic income (real value added). 


\section{References}

Arvanitis, Spyridon, and Thomas Bolli (2008), „Qualifikation der Arbeitskräfte, Migration und die bilateralen Abkommen mit der EU“, in: KOF Swiss Economic Institute (ed.), Auswirkungen der bilateralen Abkommen und die Schweizer Wirtschaft, Zurich, pp. 69-87.

Basu, Susanto, John Fernald and Miles Kimball (2006), "Are Technology Improvements Contractionary?", American Economic Review, 96, pp. 1418-1448.

Bolli, Thomas, and Mathias Zurlinden (2009), "Measuring Growth of Labour Quality and the Quality-Adjusted Unemployment Rate in Switzerland", Applied Economics Quarterly, 55, pp. 121-145.

Diewert, W. Erwin, and Catherine J. Morrison (1986), "Adjusting Output and Productivity Indexes for Changes in the Terms of Trade", Economic Journal, 96, pp. 659-676.

Hulten, Charles R. (2000), Total Factor Productivity: A Short Biography, NBER Working Paper No. 7471.

Jorgenson, Dale W. (1995), Productivity, Vol. 1: Postwar U.S. Economic Growth, Cambridge, MA.

Jorgenson, Dale W. (2005), "Accounting for Growth in the Information Age", in: P. Aghion and S. Durlauf (eds.), Handbook of Economic Growth, Vol. 1A, Amsterdam, pp. 743-815.

Jorgenson, Dale W., and Zvi Griliches (1967), "The Explanation of Productivity Change", Review of Economic Studies, 34, pp. 349-383.

Jorgenson, Dale W., and Kevin J. Stiroh (2000), "Raising the Speed Limit: U.S. Economic Growth in the Information Age", Brookings Papers on Economic Activity, 1, pp. 125-236.

Kohli, UlRich (1993), "GNP Growth Accounting in the Open Economy: Parametric and Nonparametric Estimates for Switzerland", Swiss Journal of Economics and Statistics, 129, pp.601-615.

Kohli, Ulrich (2004), "Real GDP, Real Domestic Income, and Terms-of-Trade Changes", Journal of International Economics, 62, pp. 83-106.

Organization for Economic Co-operation and Development (OECD) (2001), OECD Manual - Measuring Productivity: Measurement of Aggregate and Industry-Level Productivity Growth, Paris.

Oulton, Nicholas, and Sylaja Srinivasan (2003), Capital Stocks, Capital Services, and Depreciation: An Integrated Framework, Bank of England Working Paper No. 192. 
Ritzmann-Blickenstorfer, Heiner (1996), Historical Statistics of Switzerland, Zurich.

Rudolf, Barbara, and Mathias Zurlinden (2009), "Measuring Capital Stocks and Capital Services in Switzerland", Swiss Journal of Economics and Statistics, 145, pp. 61-105.

Solow, Robert M. (1957), "Technical Change and the Aggregate Production Function", Review of Economics and Statistics, 39, pp. 312-320.

Swiss Federal Statistical Office (SFSO) (2006a), Productivité multifactorielle - rapport méthodologique, document de travail, octobre 2006, Berne.

Swiss Federal Statistical Office (SFSO) (2006b), Stock de capital nonfinancier-rapport méthodologique, document de travail, octobre 2006, Berne.

Tinbergen, Jan (1957), „Zur Theorie der langfristigen Wirtschaftsentwicklung“, Welt-wirtschaftliches Archiv, 55, pp. 511-549.

\section{SUMMARY}

In this paper, we analyse the sources of economic growth in Switzerland during the period 1991-2006. The results suggest that labour input and capital input contribute $0.52 \mathrm{pp}$ and $0.57 \mathrm{pp}$, respectively, to the average annual GDP growth of $1.44 \%$. The remaining $0.35 \mathrm{pp}$ represent growth in multi-factor productivity, which is calculated as a residual. The estimate of growth in multi-factor productivity is lower than in previous studies because our measure of labour input takes changes in labour quality into account. Changes in labour quality explain 0.39 pp of the $0.52 \mathrm{pp}$ contribution from labour input. 